\title{
The Effect of Photovoice on Speaking Skills At The Secondary School Level
}

\author{
Rifqi Aziz Hidayat ${ }^{1}$ \\ Universitas Pancasakti Tegal \\ Rifqiayat@gmail.com \\ Rofiudin $^{2}$ \\ Universitas Pancasakti Tegal \\ Rofiudinza.ups@gmail.com \\ Endang Sulistianingsih ${ }^{3}$ \\ Universitas Pancasakti Tegal \\ Endang.sulistia@gmail.com
}

\begin{abstract}
The students need to be fluent in speaking to express their ideas and what they think in their mind also to communicate with others. As a matter of fact, speaking using Bahasa is not a big deal for students since it is their mothertongue, but as they have to speak in English it becomes a big problem. They can't imagine what they want to speak, they afraid and unconfident if they try to speak English, therefore the teacher should provide the students motivation to speak up and use the appropiate method in teaching speaking.Photovoice is a suitable method that using camera for supporting the process of teaching-learning. The purpose of the study isto identify the effect of using Photovoice on speaking skill at secondary school level. We used speaking test to complete and process the data. The participants of the study were the students at the secondary level. The outcome of the study revealed that the students who taught using Photovoice had better skill in speaking English thanthe students who were not taught using Photovoice. Through this method the students become interest and active during study.They seemed enjoy and excited in exhibition or presentation.
\end{abstract}

ARTICLE HISTORY

Received 13 August 2019 Accepted 14 October 2019

\section{KEYWORDS}

Abstracts; academic words

\section{Introduction}

Speaking is one of our most complex cognitive, linguistics, and motoric skills. One needs speaking to give or receive information (Bailey \& Nunan, 2005). Sometime when someone conveys the information to others, not only using speaking bu also using gesture or body movement to support what they meant. Based on our observation, speaking skill especially in English for EFL students at the secondary level, are crucial matters since many students quiet and passive in the class. They still 
struggle with grammar and pronunciation. The other matter is sometimes their classmates laugh at them because they make mistakes in spelling. The lack of vocabulary is also another matter to be encountered. All those matters make the students become less confident in speaking English.

Some experts give a solution for developing students' speaking ability, they suggest various methods, and one of the methods is Photovoice. Wang \& Burris(1997) define Photovoiceas as an activity which is involved photographic to introduce their society. In the teaching and learning process, the students take some photos with their group, deciding together to describe each photo by using their own ideas in order to tell what happens in there Wang \& Burris(1997).It makes it easier for the students to combine photos that they have taken and then describe the photo in spoken form. In the study, photovoice means the message contained in the photo is described by the students in spoken form. The research related to Photovoice is conducted by Dwi et al. (2018), it focuses on speaking class with teachers' questions and Photovoice.The result of their research is teachers' questions, and Photovoicemake students develop their speaking skills.Putri(2018) applied Photovoice in teaching English guiding, and she states that trough Photovoice students' speaking skill is improved. Furthermore, some researchers say that Photovoice effective in writing because Photovoice helped students visually, focused, and development as effective writers (Zenkoev,Harmon. 2009). Other research that applied Photovoice is done byDicicco (2014). He uses Photovoice to develop students' reading comprehension. The result of the research indicated that Photovoice helpful for students' comprehension, and it eliminates the opinion that reading is boring and difficult. This research wants to find out the effect of Photovoice on students' speaking skill especially at the secondary school level.

\section{Review of Related Theory}

Ones express a feeling, opinion, and information. Speaking is producing sound to convey the meaning orally (Nunan, 2003). We, as social humans, use speaking to make conversation with others, exchange the information, share the feeling, wish and etc. So speaking is very important because: (1) Language is a mechanism for communication. (2) For the smooth running of any system, if the speaker did not speak up smoothly, it makes miss understanding between communicator and communicant. (3) In order to become a good communicator, one needs to be proficient in many skills such as listening, speaking, reading, and writing. (4) An effective speaker can get the attention of the audience and can share information clearly (Qureshi, 2012).

In the activity of learning language, speaking has criteria that support in teaching, Brown (2003)states there are effective ways and criteria in the test. Those criteria are classified in term of many forms of speaking performance: (1) Imitative is 
activity when the student just repeat what the teacher says or what the communicator says, and the communicant just try to repeat in the spoken form, (2) Intensive is the activity when the teacher doesn't give an explanation of how to pronounce but ask them to read aloud text and check their communication, (3) Responsive, an activity when the students try to how to give a respond (feedback)or make conversation, (4) Interactive is similar to responsive, and the difference is the participant and topic, but in the process of interactive there are two or more student, (5) Extensive this is the last of oral production, in this process the student will try to produce a monologue text.

Teaching speaking seems so difficult and challenging for English teachers; many students have the same difficult to speak up their expressions, feelings, opinions, and wishes in front of the class. Because the student scares to makes a mistake, shy to speak up, and lack of vocabulary. Sometimes if the student speaking in front of his classmates, his friends laugh at him since he makes some mistakes.Therefore the teacher should have many ways to make the students more confident or enjoyable in the teaching-learning process. The teacher should give the students the chance to speak up or practice speaking in front of the class so that the students enjoy practicing speaking to express their ideas.

There are many ways in teaching to make the students more enjoy, relax, comfort, and enthusiasm in the classroom activities, and of course, to make it happen, the teacher should be more creative in creating activities in the teachinglearning process.The ways can be using digital media in teaching the students, change the old method to a new method, which is easier to apply or practice in the classroom. One of the methods appropriate to solve students' problems in speaking skill is Photovoice. Caroline Wang and Mary Ann Burris introduce the method in the 1990s, the method has the activity that the people take a photo with photographic technique, then the photo can be analyzed and described(Wang \& Burris,1997).Then Strack, Magill, \& McDonagh (2004) state the participants in the Photovoice process study how to use cameras and take object photo in society, then tell the strength and weakness. Palibroda, Krieg, Murdock, \& Havelock (2009) state that Photovoice is an activity that uses photography in the group or individuals with the result of the photo, it makes their understanding of a community issue.

According toVelea \& Alexandru, 2017 applying Photovoice has many benefits in teaching-learning process, such as: (1) improve written and oral communication, (2) develop teamwork skills, (3) creates powerful visual materials, (4) stimulates creativity and spirit of initiative, (5) improve self-esteem, (6) stimulating reflection on reality. Besides it has benefit, it also has limitations in the teaching-learning process, which are: (1)The time needed is relatively long, needed time management. (2)Participants were getting trouble to express their ideas about their photos. (3)A deep analysis of the problem can also cause negative feelings.(4)The students should 
be warned of this risk, damage, and losing the camera. (5) The activities must be monitored to know the progress of the students in the activity.

\section{Methodology}

The research used quantitative research. We used quantitative research because we wanted to find out about the effect of Photovoice on speaking skills. To know it, we must calculate the numeric data from the test given to the students after using Photovoice. In collecting data, we used a speaking test that included: Grammar, Vocabulary, Comprehension, Fluency, and Pronunciation. Then to make accurately took the result of data, we met face to face with students directly, and we used the recorder to re-listen the students' voice one by one. The speaking test was explained the photo, especially natural disaster, and the topics were determined by us, the topics were earthquake, flood, and rainbow. Then the students had 3 minutes to explain the photo. The population was also the sample; they were the students of senior high school in Pemalang. The total numbers of students were 60. The students were in the second grade when the writer had conducted the research.

The observation was conducted before the treatment. In this study, we used experimental research as a type of research; experimental research is a research method used to look for the effect of treatment.Generally, one or more variables are manipulated to determine their effect on the dependent variable. We conducted the research in two group design, in a different class, but in the same grade. We took the class with the total of the students who were the same to collect the data. The first class that we selected as the experimental group that gave treatment used the Photovoice method. And the second class as a control group, we used as the comparator.

In applying the Photovoice we taken fromPhotovoice path by Wang \& Burris (1997), the steps begin Phase 1: introduced Photovoice, Phase 2: take photographs using camera, Phase 3: discussing the result of the Photograph, Phase 4: writing text, Phase 5: selection the photo, Phase 6: invite people to share in discussion, Phase 7: options to present an exhibit.

\section{Result}

We conducted the research in eight meetings in two classes as a sample. There was an Experimental group and Control group. In teaching the Experimental group, we used Photovoice, and in the Control group, we did not use Photovoice. Describe the activity of research in Experimental group as below:

\section{Treatment}

The first meeting was conducted on Thursday, $21^{\text {st }}$ of March 2019. We introduced the method, explained the concept of the method and benefits of this 
method, the students looked interested in the method, and we got full attention from the students. The second meeting was conducted on Monday, $25^{\text {th }}$ of March 2019. We explained about explanation text, social function, and generic structure based on the example that we gave before. Then the students wrote the example of the text about a natural disaster that the writers wrote and explained in front of the class. The students understood directly because the English teacher explained before we came into this class, and we suggested to the students to read the text to know pronunciation students. Then the students couldn't read; clearly, they struggled in pronunciation and fluency, they looked nervous.

The third meeting was conducted on Tuesday, $28^{\text {th }}$ of March 2019 . We gave the material like in the second meeting and talked about the grammar of explanation text. We gave the text again, and then the students read one by one like in the second meeting. The students read three sentences until one paragraph, and we corrected their speaking. Then the students looked confident but still struggled in pronunciation and fluency.

The fourth meeting was conducted on Monday, the $1^{\text {st }}$ of April 2019. We repeated the material again like in the second and third meeting to make sure the students understood about the material, and to make the students good in pronunciation. Then we suggested the students made a group consisted of 5 until 6 students. Every group must bring one handphone to take a photo. After that, the students went out of the class and took the photo around the school. But in taking a photo, the students faced difficulties. They were confused to take a photo because the students did not pay attention if we gave instructions, and students were not cooperating well; even some students made a joke with the others. 
The fifth meeting was conducted on Tuesday, the $4^{\text {th }}$ of April 2019. We suggested the students selected the photos that the students took before. And the students tried to write the text based on their photos. In these activities, many students feel confused, what they should do first. Then we explained instructions to make it easier and helped the students arranged the words.

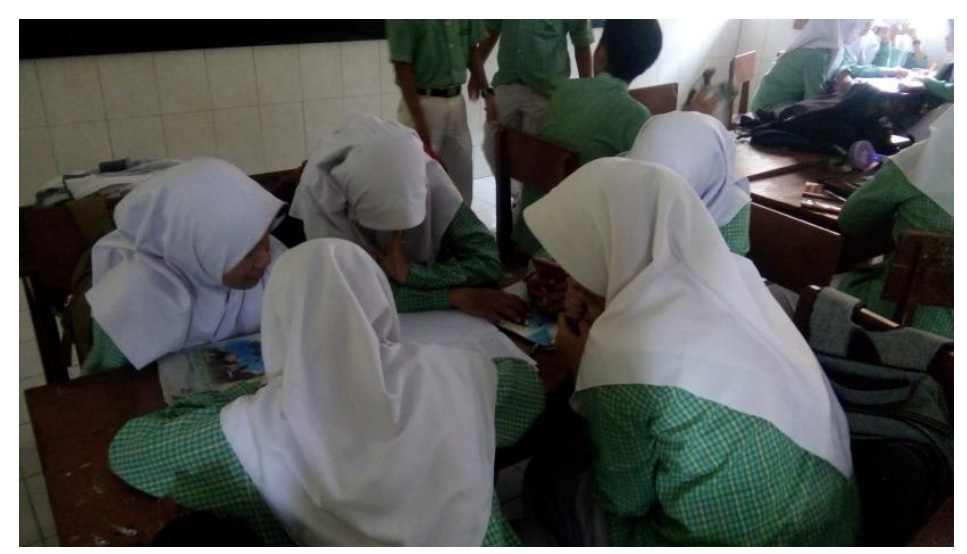

Figure1. The students work in a group.

In work in a group, the students stated that when we explained instructions such as $5 \mathrm{~W}+1 \mathrm{H}$ questions. It is very effective, caused it to guide the students easier to arrange the words to become a paragraph. They could express their ideas by answering questions based on $5 \mathrm{~W}+1 \mathrm{H}$, such as:

- What do you see here?

- What happening here?

- Why does a situation exist?

- Etc.

The sixth meeting was conducted on Tuesday, $11^{\text {th }}$ of April 2019. The students continued to complete writing their text and make sure that they had a good preparation for the presentation in front of the class in the next meeting.

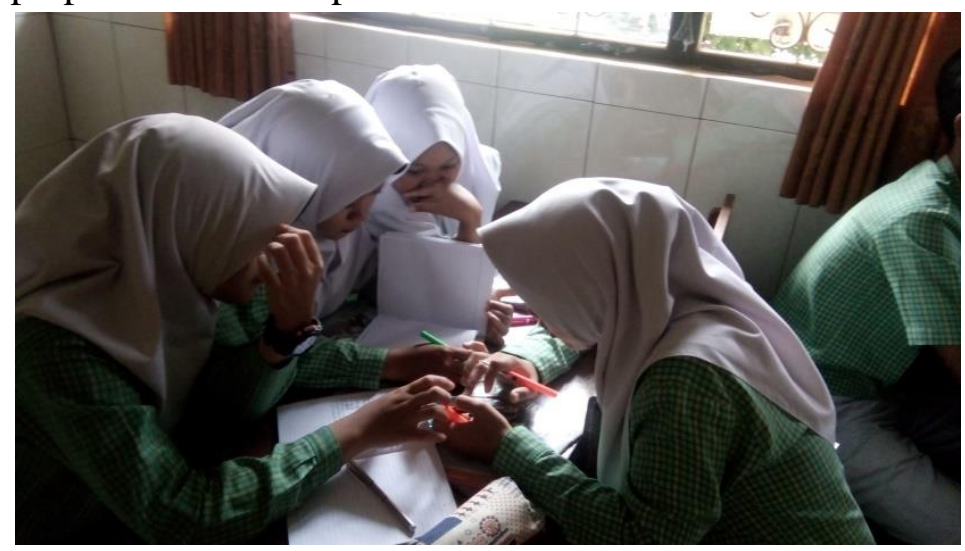

Figure2. The students work in a group. 
Based on this figure above, we could see that the students very seriously to finish their writing. They used a handphone to help search the vocabulary that they wanted; then the other students tried to arrange word by word become sentences.

The seventh meeting was conducted on Monday, $15^{\text {th }}$ of April 2019. We set up a display with an LCD projector to help the student presentation, and to make interested. Many photos were shown in front of the class. Then the students saw their friends' presentation in forward, explained the photos; students argued the photos, and exchanged information. In reality, the students felt confident to speak up in forward, although they still struggled in pronunciation, all presentations were well done.

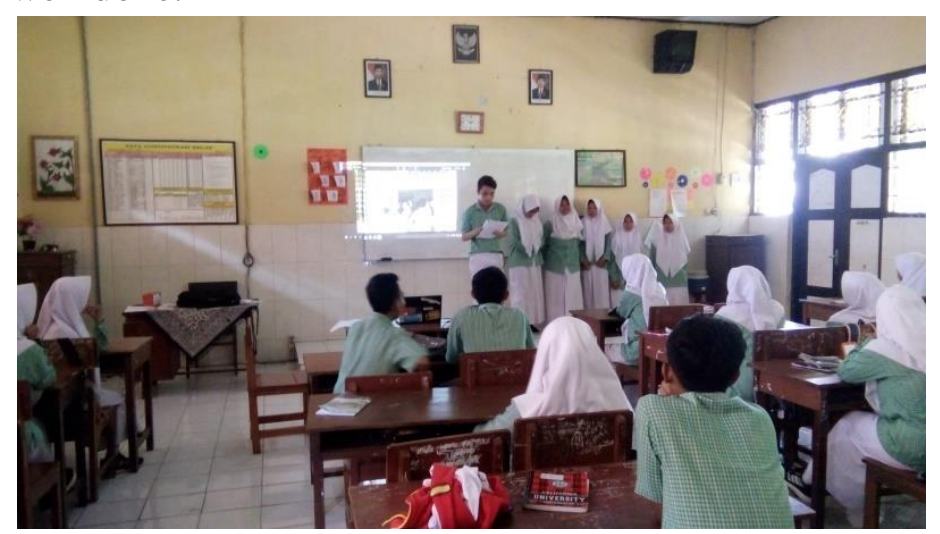

Figure3. Presentation.

Based on the figure above, we could see that used Photovoice collaborate with LCD Projector could make the students interested and felt enthusiastic. They could see many photos showed in forward, and also, the students could give an opinion based on the presentation to their friends.

2. Result of Students' Photographic

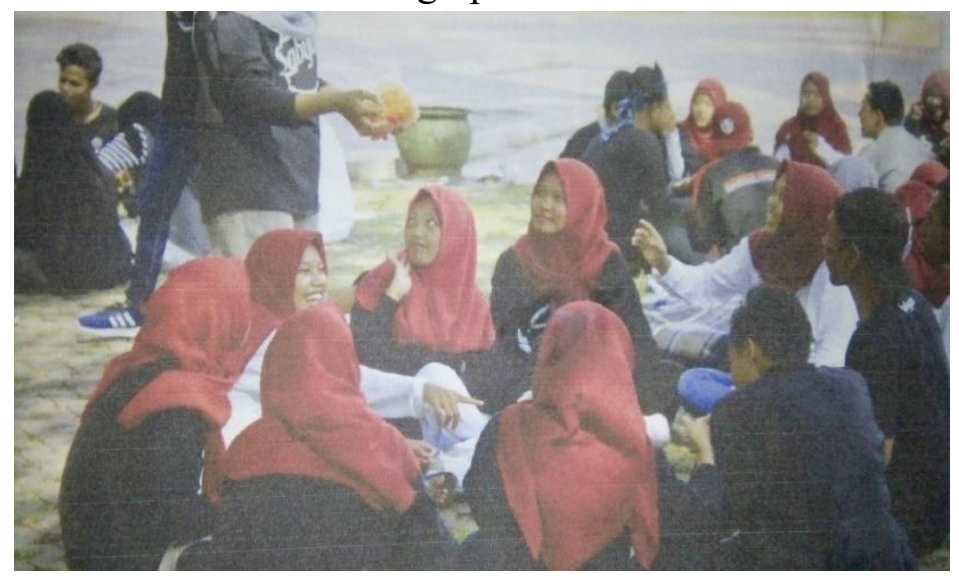

Figure4. Social Group, by Nanda, Neysa, Putri, Refina, Ristiana, Risky. 
Social groups are groups of people who have a shared awareness of membership and interact with each other. The purpose of make a group is to sharing and getting information.

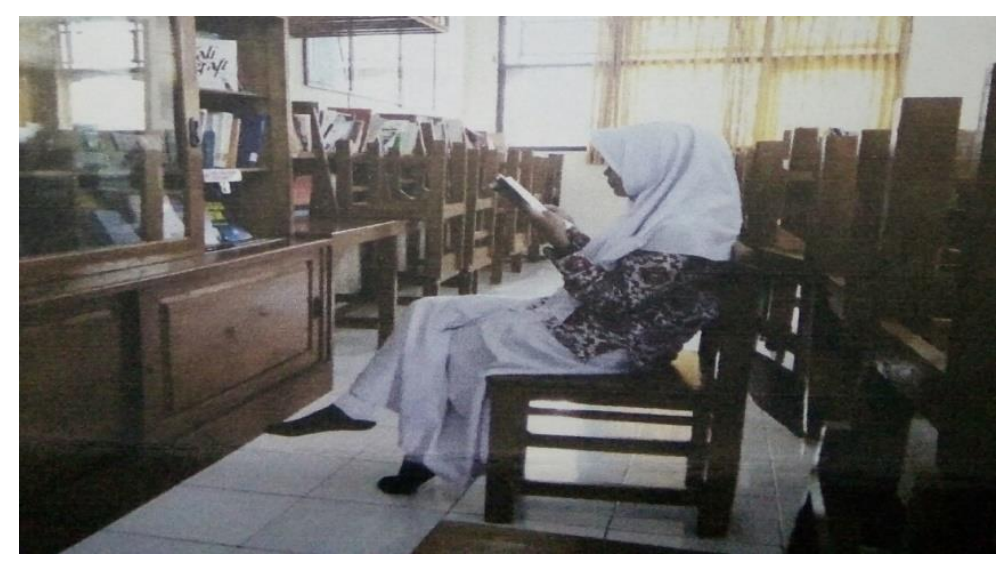

Figure 5. Library, by Ahmad, Dhea, Dwi, Mudia, Sus, Tegar.

The library is a place to read, add insight, increase knowledge, and place to do exercise. The situation in the library is students who are reading or looking for an answer through books in the library; the library is a very important place that must-have in every school because the library becomes a place to find out much knowledge and sources about education.

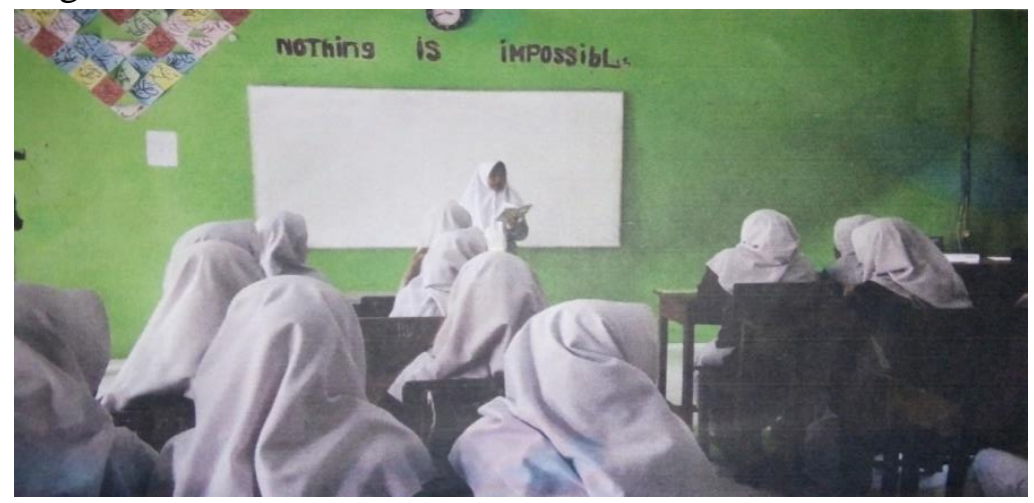

Figure 6. Organization of Adolescent Mosque, by Asti, Diah, Irna, Mila, Yusuf, Yoga.

The adolescent mosque is a gathering of mosque young men who carry out social religious activities, which is the organization in the state of senior high school in Pemalang, we called IRMA. 


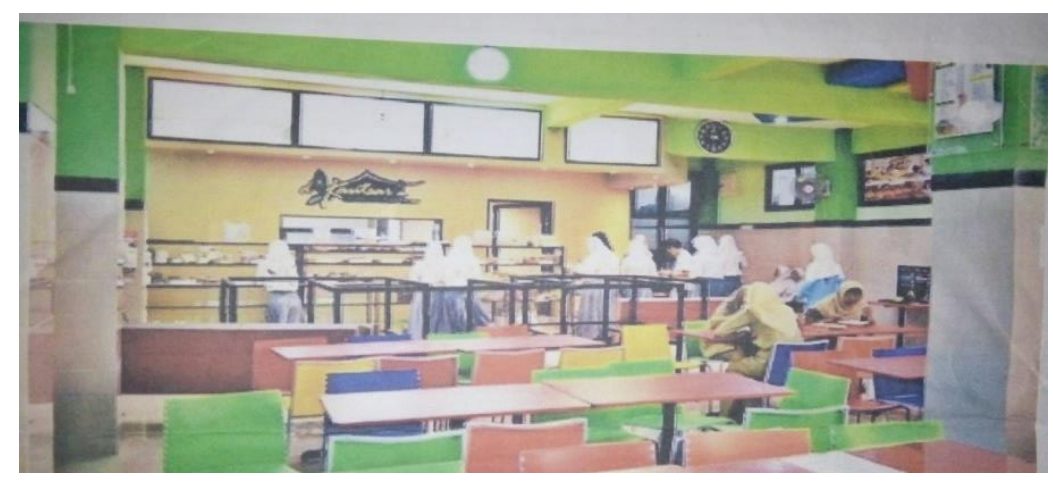

Figure 7. Canteen, by Hanif, Alhidayah, Indah, Muliya, May, khaonaeni.

The canteen is a room in a public building that can be used by students to eat, not only to eat, the canteen also the place that the students were gathering and sharing information with others.

After conducting the treatment, we gave a speaking test to the experimental and control group to find out the significant difference of implementingPhotovoicein the research and to know about the effect of Photovoice on the students' speaking skills.

The speaking test was conducted on Tuesday, $18^{\text {th }}$ of April 2019. In the process of collecting the data, we met face to face with the students directly, and we used the recorder to re-listen the students' voices one by one. The speaking test explained the photo, especially natural disaster, with the topics that determined. The topics were earthquake, flood, and rainbow. Then the students have 3 minutes to explain the photo.

The results of the speaking Test of Experimental Group and Control Group to see whether or not it gives positive effect to the students, we need to calculate the result of mean, median, modus, the standard deviation of variant between experimental group and control group. They are compared to get further data. Before analyzing the data, there was the result of calculated independent sample ttest, as follows

Table1. Independent sample t-test

\begin{tabular}{cccc}
$\begin{array}{c}\text { Levene's Test for } \\
\text { Equality of } \\
\text { Variances }\end{array}$ & t-test for Equality of Means \\
\hline & & &
\end{tabular}




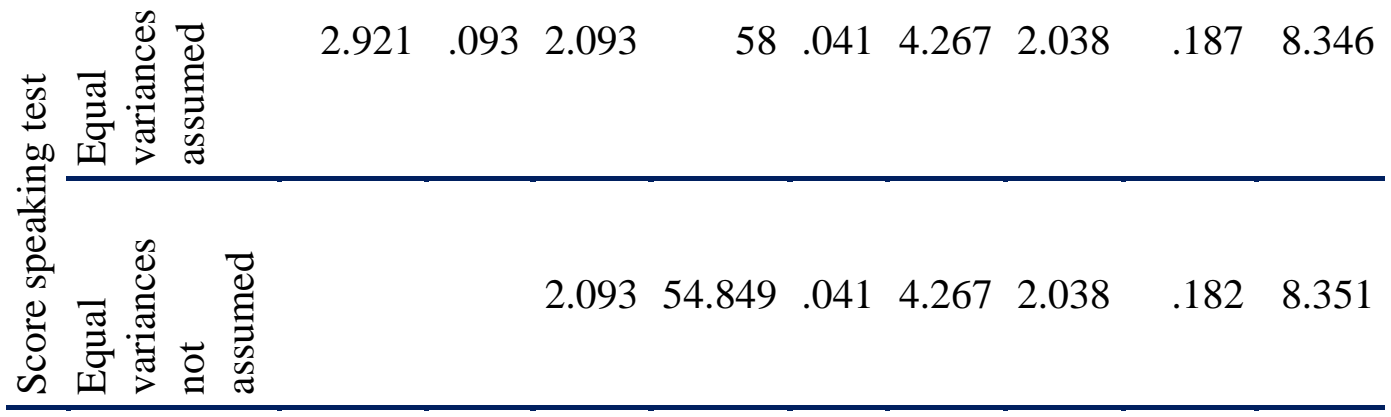

From the computation data above, the result of computing t-test on the data above showed 2.093 with Df $30+30-2=58$; it is obtained t-table was 1.672 . So it concluded that the $t$-value was higher than the t-table $(2.093>1.672)$. It means that Photovoice had a positive effect on students' speaking skills. 


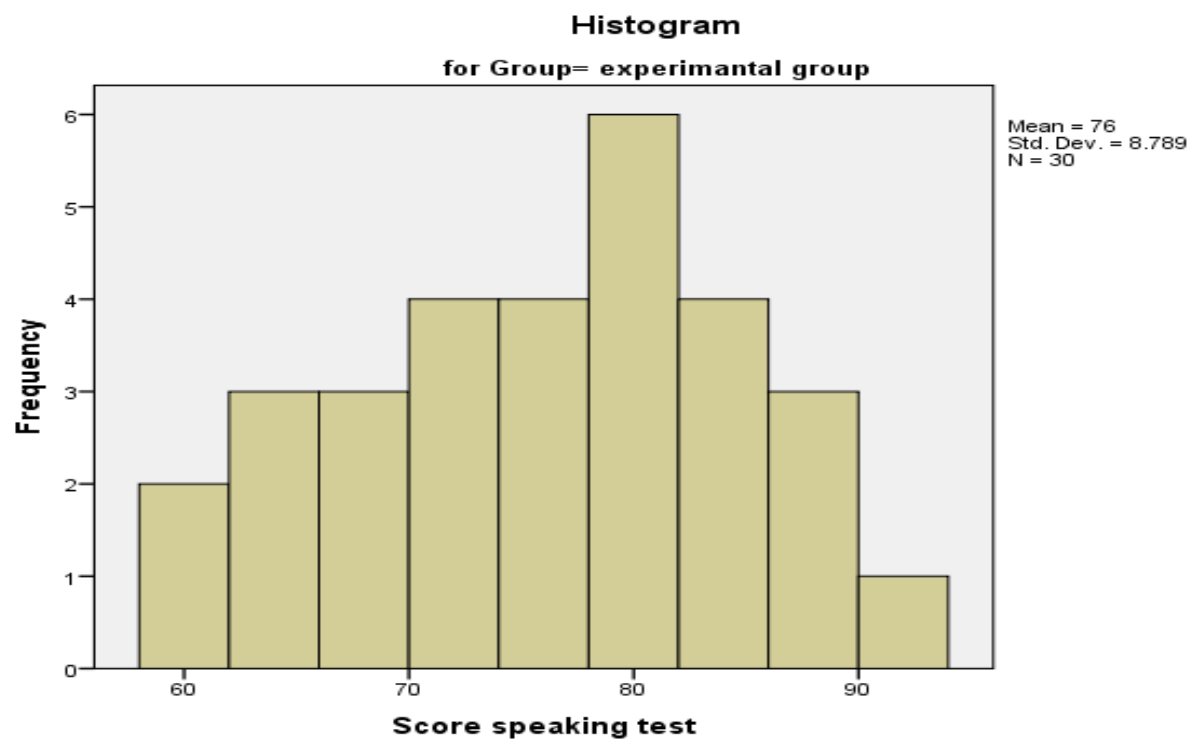

Figure 8. Histogram the result of Experimental group

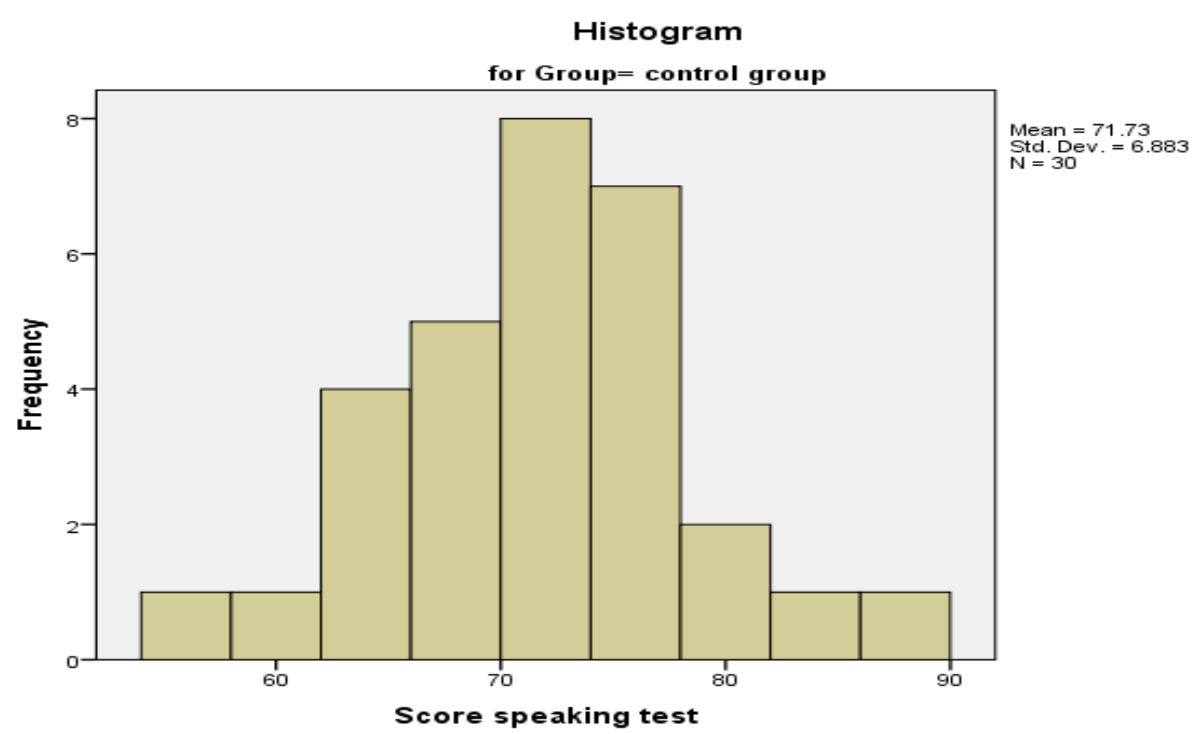

Figure 9. Histogram the result of Control group

Based on Figure.1 and figure.2, it concluded that the result of the speaking test experimental group had a better result than the speaking test of the control group, It means that the experimental group had better efforts in learning speaking by Photovoice. In the activity of the research in the experimental group, the students felt interested in the teaching-learning process, because in the activity of teachinglearning, many activities that used by Photovoice, such as the students taking photos, group discussion, showed photos, an exhibition or presentation. 


\section{Discussion}

Based on the result, it revealed that photovoice is an effective method to improve the student's speaking ability. Photovoice is an interesting method because there are a lot of things in the surroundings that can be taken as an object of the photos that to be discussed. The students could choose their photos based on their interests. The photos could be used as a device for discussion. Various kinds of photos showed in the class could avoid students' boredom.In this research, we used the Photovoice Path taken from (Wang \& Burris,1997) to teach them, such as: In the Phase 1: introduced Photovoice, Phase 2: take photographs using camera, Phase 3: discuss Photograph, Phase 4: writing text, Phase 5: selection the photo, Phase 6: invite people to share in discussion, Phase 7: to present and exhibit. Unfortunately, in reality, the writers applied the modification path. We modify some rules that are appropriate in the situation of the students.

The modification path are: in phase 2 until 3 we gave the students materials about explanation text, to make sure that the students understood in the material, trained the students about spelling well by reading text one by one, and also make easier the students in process writing such as arrange the word become good sentences, because the students little confused in the activity, and still struggle in spelling pronunciation. Afterward, we applied the activities of taking a photo in the fourth phase. To make the students easier in this activity, the students just used a camera from their cellphone instead of using the digital camera. Then in the last phase, we used the LCD projector to attract the students' attention.

Based on Velea \& Alexandru(2017) applying Photovoice has many benefits like, improve written and oral communication, develops teamwork skills, creates powerful visuals materials, stimulates creativity and spirit of initiative, improve selfesteem, stimulating reflection on reality, but in the second grade students on senior high school in Pemalang we found the students improve their written and oral communication, develops teamwork, create powerful visuals materials, and improve self-esteem, stimulate reflection on reality and develop critical way of thinking. So the result of the research, we agreed with the statement above, and we added that Photovoice also develops a critical way of thinking. Velea \& Alexandru(2017) state that the limitations of Photovoice are: The time needed is relatively long, needed time management.Participants got trouble to express their ideas about their photos. In a deep analysis of the problem can also cause negative feelings. The students should be warned of this risk, damage, and losing their camera. The activities must be monitored to know the progress and the result of the students.

We found that there are limitations from the implementation of Photovoice when conducted research at second grade students in Pemalang: there was a long time, or wasted time in the process of taking photo, because the students did not focus on what their need, the students sometimes made a joke with other students and 
it wasted time. When the process of writing, there were the students still confused and may have trouble expressing their ideas because they still joked with other friends, and we tried helped the students to solve the problems with gave instructions. In the process of taking photos the students just used the camera from their handphones, so it was very difficult for the students if they did not bring a handphone.

We always monitored the progress because, in the method, the students are involved in the teaching-learning process. We just facilitated and guided the students if they got trouble or felt confused during the activity, and made sure that the activity in this method was appropriate with what we wanted. This method is very effective if the teacher implements it in a relaxed situation. Students can sit and look at the other student's presentations in front of the class with various photos that are shown. It will be more exciting if it is supported with an LCD projector, and the teacher can manage the time of all activities well..

\section{Conclusion}

Photovoice is not only effective for students but also makes the student interested and motivated in learning speaking. The students also able to express their creativity through the camera; they seem to enjoy the activity of taking the photo. In addition, they can sharpen their critical thinking and expressing ideas through the presentation. Their ability to describe or to visualize the photo was revealed through the presentation.

Even though the whole activities in Photovoice make the students' speaking skill was improved but the time to take the photo is time-consuming if the teacher can't manage the time. The students sometimes get easily distracted since they like joking with their pairs while taking a photo. Also, most of the students feel uneasy when composing the photo description; this means that the teacher should pay attention to guiding the lesson. 


\section{References}

Bailey, K. M., \&Nunan, D. (2005). Practical English language teaching: speaking.New York: McGraw-Hill ESL/ELT

Brown, A. (2003). Interviewer variation and the co-construction of speaking proficiency.Language Testing, 20(1), 1-25.

Dicicco, M. (2014). Picturing the Reader: English Education Preservice Teachers Beliefs About Reading Using Photovoice. Dissertation. University of South Florida

Dwi, D., Megawati, A., Ari, D., Nurhayati, W., \& Pangestu, B. S. (2018). Photovoice: Exploring the Role of Teacher' $s$ Question for University Students ' Fluency in Speaking Class, 2(2017), 17-26.

Nunan, D. (2003). Second language teaching and learning .Foreign Language Teaching and Research Press.

Palibroda, B., Krieg, B., Murdock, L., \& Havelock, J. (2009). A practical guide to photovoice: Sharing pictures, telling stories and changing communities. Winnepeg, Manitoba: Prairie Women's Health Centre of Excellence (PWHCE).

Putri, G. A. (2018). Photovoice Implementation in Teaching English Guiding at English Study Program College of Foreign Language (STIBA) Saraswati Denpasar. English Focus: Journal of English Language Education, 1(2), 8695.

Qureshi, I. A. (2012). THE IMPORTANCE OF SPEAKING SKILLS FOR, (5655), $1-10$.

Strack, R. W., Magill, C., \&McDonagh, K. (2004).Engaging youth through photovoice.Health Promotion Practice, 5(1), 49-58.

Syakur, M. (1987).Language testing. Surakarta: UNS Press.

Velea, S., \& Alexandru, M. (2017). PhotoVoice_Connector, 1-17. Retrieved from https://www.erasmusplus.ro/library/files/Ghiduri COnnector 2017/PhotoVoice_Connector 2017.pdf 
155 | VISION: JOURNAL FOR LANGUAGE AND FOREIGN LANGUAGE LEARNING

Wang, C., \& Burris, M. A. (1997).Photovoice: Concept, methodology, and use for participatory needs assessment. Health Education \& Behavior, 24(3), 369-387.

Zenkoev, Harmon (2009). Picturing a Writing Process: Photovoice and Teaching Writing to Urban Youth, 52(April), 575-584. https://doi.org/10.1598/JA 